\title{
Relationship between the school backpack load and university students' posture
}

\author{
Relação entre a carga da mochila escolar e postura de estudantes universitários
}

\author{
Thiago Pereira Veronese $\left(\mathbb{D} 1\right.$, Iracimara de Anchieta Messias $\left(\mathbb{D} 2 \bowtie\right.$, Diego Giulliano Destro Christofaro ${ }^{(\mathbb{D})}$, \\ Dalva Minonroze Albuquerque Ferreira (D) 1
}

\author{
Department of Physical Therapy, School of Technology and Sciences São Paulo State University (UNESP). Presidente Prudente, São Paulo, Brazil. \\ 2 Department of Planning, Urban Planning and Environment, School of Technology and Sciences, São Paulo State University (UNESP). \\ Presidente Prudente, Sã̃o Paulo, Brazil. \\ ${ }^{3}$ Department of Physical Education, School of Technology and Sciences, São Paulo State University (UNESP). Presidente Prudente, São Paulo, Brazil.
}

How to cite this article:

Veronese TP, Messias IA, Christofaro DGD, Ferreira DMA. Relationship between the school backpack load and university students' posture. Sci Med. 2019;29(3):e33440. http://doi.org/10.15448/1980-6108.2019.3.33440

\section{ABSTRACT}

AIMS: To relate the effect of progressive increases in the load of the school backpack with the posture of university students.

METHOD: Twenty-six female university students from the physiotherapy course, aged between 18 and 25 years, were evaluated. Loads of $0 \%, 3 \%, 5 \%, 7 \%$, and $10 \%$ of the volunteers' body weight were placed in a backpack on the shoulders of the volunteers. Next, images were captured in the right sagittal plane, processed through Postural Assessment Software (SAPO). The statistical analyzes were performed using Analysis of Variance test.

RESULTS: The results obtained demonstrated significant differences in the angles between the elbow and the anterior superior iliac spine when carrying $7 \%$ compared to $0 \%(\mathrm{p}=0.001)$; and the acromion and anterior superior iliac spine comparing $7 \%$ with $0 \%$, ( $\mathrm{p}=0.032)$. In the other measurements, there were no significant differences.

CONCLUSION: Loads from 7\% of body weight are sufficient to promote postural changes.

KEYWORDS: Posture; weight-bearing; young adult; spine.

\section{RESUMO}

OBJETIVOS: Relacionar o efeito do aumento progressivo da carga da mochila escolar com a postura de universitários.

MÉTODO: Vinte e seis universitárias do curso de fisioterapia, com idade entre 18 e 25 anos, foram avaliadas. Cargas de $0 \%, 3 \%, 5 \%, 7 \%$ e $10 \%$ do peso corporal foram colocadas em uma mochila nos ombros dos voluntários. Em seguida, foram capturadas imagens no plano sagital direito, processadas através do software para avaliação postural (SAPO). As análises estatísticas foram realizadas utilizando Análise de Variância. RESULTADOS: Os resultados obtidos demonstraram diferenças significativas nos ângulos entre o cotovelo e a espinha ilíaca ântero-superior ao carregar $7 \%$ em comparação com $0 \%, p=0,001$; e o acrômio e espinha ilíaca ântero-superior comparando 7\% com $0 \%, p=0,032$. Nas outras medições, não houve diferenças significativas.

CONCLUSÃO: Cargas a partir de 7\% do peso corporal são suficientes para promover alterações posturais.

DESCRITORES: Postura; suporte de peso; jovem adulto; coluna vertebral. 
Abbreviations: ASIS, anterior superior iliac spine; BMI: Body mass index; $\mathrm{C} 7,7^{\text {th }}$ cervical vertebrae.

\section{INTRODUCTION}

The two-handle backpack is one of the most practical and commonly used methods for students to carry school supplies, usually supported on the back or bilateral shoulder $[1,2]$. When it is too heavy, the backpacks can cause alterations in the trunk posture, generating complaints of pain in the low back, neck, and shoulder [3]. In the United States, more than $92 \%$ of children carry backpacks that weigh between $10 \%$ and $22 \%$ of their body weight [4]. Another study pointed out that $68.37 \%$ of children from the 1 st to 5 th year of a private school in the city of Canoas, Rio Grande do Sul state, carried loads above the tolerance range of $10 \%$ of their total body weight [5]. Complaints are more common in female young people and, according to evidence, musculoskeletal pain in childhood and adolescence is a significant risk factor for presenting these symptoms in adulthood [6]. Women are more exposed to postural alterations when compared to men, as they have the habit of carrying more items of daily use in their bags and backpacks, which can make the backpack load too heavy, contributing to the appearance of corporal compensations and postural alterations [7].

It is known that the recommended weight for the use of the school backpack is up to $10 \%$ of body weight, without causing problems for the user, and that backpacks with 10 to $15 \%$ of the body weight are acceptable, although generating some postural damage. On the other hand, backpacks weighing more than $15 \%$ are unacceptable since they cause damage to the physical and mental health of users. Although these values are also adopted by the Brazilian Society of Pediatric Orthopedics, a study published in 2015 observed postural alterations from a backpack weighing $11 \%$ of the child's body weight $[8,9]$. In this way, it is understood that any load exceeding $11 \%$ of the individual's body weight can be harmful and potentially cause postural alterations. In the state of Rio de Janeiro, there is a law recommending that the maximum weight of school material carried by pre-school and 1st grade students should not exceed $5 \%$ of the weights of pre-school children and $10 \%$ of elementary school children [9].

Although the scientific community has not yet identified the critical backpack weight above which the individual would be subject to spinal problems, a literature review pointed out that a weight limit of $10 \%$ to $15 \%$ of body weight is recommended as the maximum load for school children, based on epidemiological, physiological, and biomechanical approaches [8]. However, several authors agree that the load of the school backpack should have a maximum limit of $10 \%$ of the body weight of its user, or even lower values [5, 10-12]. Indeed, the studies carried out indicate a load limit or ideal maximum load in backpacks of $10 \%$ of body weight, this value being adequate for transportation without causing postural alterations.

There are no studies that analyze changes below this value. Thus, the objective of the present study was to correlate the effect of progressive increases in school backpack load, ranging from $0 \%, 3 \%, 5 \%, 7 \%$, and $10 \%$ of body weight, on the posture of university students, considering the trunk, pelvis, and upper and lower limbs. Our hypothesis was that loads in school backpacks weighing less than $10 \%$ of body weight would possibly cause postural alterations.

\section{METHODS}

\section{Participants, Ethic Aspects and Study Design}

The volunteers invited to participate in the study were selected for convenience and accessibility. The choice to include students from the physiotherapy course of the São Paulo State University, School of Technology and Sciences, in Presidente Prudente, São Paulo state, Brazil. This choice occurred because this population had prior knowledge on correct posture. The exclusion criterion considered individuals who presented Body Mass Index (BMI) above 35, considered as grade II obesity; that was in pregnant or lactating; that practice laboral activities outside the university routine; that practice physical activities of strong intensity according to the International Physical Activities Questionnaire, or presenting body deformities that prevented the visualization of reference points.

The study was carried out at the Laboratory of Work Biomechanics of the Centre of Studies and Research in Ergonomics of São Paulo State University, in Presidente Prudente Campus. The research was submitted to evaluation by the Ethics in Research Committee of School of Technology and Sciences, São Paulo State University, being approved under the number 58489315.7.0000.5402. Subjects filled out an Informed Consent Form, agreeing to participate in the study. 


\section{Data collection}

Initially, the weight of each participant was measured, in order to define the percentages of $3 \%$, $5 \%, 7 \%$, and $10 \%$ of their weights. Then, markers were placed on some strategically chosen anatomical points of the volunteers' bodies (Figure 1), to guide the postural analysis. We used pet bottles of different sizes, previously filled with water and weighing $2 \mathrm{~kg}$, $1 \mathrm{~kg}, 500 \mathrm{~g}, 250 \mathrm{~g}, 100 \mathrm{~g}, 50 \mathrm{~g}$ and $25 \mathrm{~g}$, to simulate the content of the backpack, representing the loads of $3 \%, 5 \%, 7 \%$ and $10 \%$ of the body weights of the participants.

Once the backpack was positioned on the volunteer's back, photographic images were taken in the right lateral view to analyze the possible asymmetries, considering different loads, $0 \%, 3 \%, 5 \%$, $7 \%$ and $10 \%$ of their body weights.

The backpack was knitted fabric, "bag" type, and weighing $150 \mathrm{~g}$. This weight was not considered for the first register (backpack without load), although it was considered in the moment of the weight increases of the backpack content. The same backpack was used in all measurements.

Postural evaluation was performed through Postural Assessment Software (SAPO). This system is a free software which provide precision and versatility to the physical evaluation process, being simple to use and inexpensive. For calibration of the software, a plumb line was used, with two red markings spaced 1 meter from each other, glued on the wire for later calibration of the photos.

Participants remained in bipodal support over a cross marked on the floor to standardize the feet position during evaluation. They were barefoot and wearing swimwear, to make it easier to visualize their actual posture as well as the markers attached to their skin, without interference during measurements. The subjects were positioned in such a way that they and the plumb line were in the same plane, perpendicular to the axis of the digital camera located three meters away and supported on a tripod at a height of about half the height of the volunteer [13].

The anatomical points recommended by the SAPO system were identified by means of circular markers of $15 \mathrm{~mm}$ in diameter and fixed on the individual through double-sided tape. The markers were of different shades, light or dark, to contrast with the volunteer's skin color.

The individual remained in front of the simetrograph, where the right sagittal frontal plane was analyzed, observing the following segments of

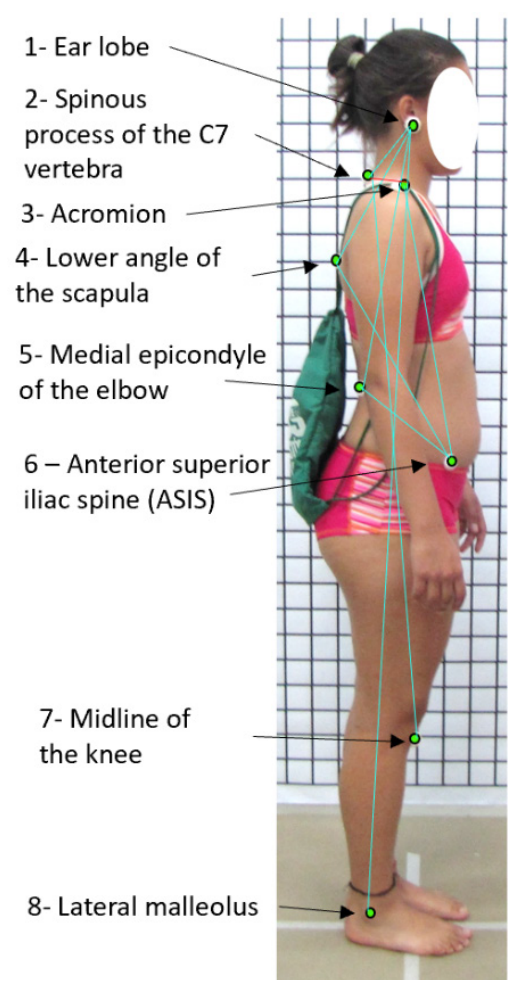

Figure 1. Anatomical points and segments analyzed (ASIS: anterior superior iliac spine; C7: $7^{\text {th }}$ cervical vertebrae).

the plane: 1 - Ear lobe; 2 - Spinous process of the $7^{\text {th }}$ cervical vertebrae (C7); 3 - Acromion; 4 - Lower angle of the scapula; 5 - Medial epicondyle of the elbow; 6 - Anterior superior iliac spine (ASIS); 7 - Midline of the knee and 8 - Lateral malleolus, as shown in Figure 1.

Also in Figure 1, it is possible to identify the analyzed segments between the points:

1. Scapula-Ear

2. Elbow-ASIS

3. C7-Joint line of the knee

4. Acromio-ASIS

5. C7-Ear

6. Elbow-Ear

7. Scapula-ASIS

8. C7-Acromion

9. Malleolus-Ear

For the accomplishment of the photographic images, the individual was oriented to adopt the neutral position, standing. In this position his right sagittal plane was observed, under the following conditions:

- Backpack with $0 \%$ of body weight.

- Backpack with weight of 3\% of body weight.

- Backpack with weight of 5\% of body weight.

- Backpack with weight of 7\% of body weight.

- Backpack with weight of $10 \%$ of body weight. 
Between the capture of one image to the next, the volunteers were allowed a rest period of approximately 5 minutes, since this was the time needed to replace the load in the backpack and put it back in their shoulders.

\section{Data analysis}

After data collection, the postural alterations from the neutral position without load $(0 \%)$ were analyzed in relation to the use of loads of $3 \%, 5 \%$, $7 \%$, and $10 \%$ of body weight. The data were organized, tabulated in an Excel spreadsheet, and analyzed by the repeated measures Analysis of Variance test. The possible differences between loads were compared by the Bonferroni post-hoc test. The magnitude of the differences was compared by measures of effect size through Eta-Squared. The statistical significance was $5 \%$ and the statistical package used was SPSS for windows 15.0. The $\mathrm{F}$ tests the multivariate effect of factor 1 . This test is based on linearly independent comparisons between pairs between the estimated means. The effect size represents a method of measuring and quantifying the effectiveness of a given intervention, treatment, or program.

\section{RESULTS}

Twenty-six female university students aged between 18 and 25 years, attended the study. Table 1 presents the characteristics of the sample. About $15 \%$ of the sample (4 volunteers) had a BMI between 25 and 30 , a value considered as overweight.

Table 1. Characterization of the sample: mean data of age, height, weight, and BMI

\begin{tabular}{lcc}
\hline Variables & $\begin{array}{c}\text { mean } \pm \text { standard } \\
\text { deviation }\end{array}$ & min - max \\
\hline Age (years) & $20.8 \pm 1.30$ & $19-24$ \\
Height (meters) & $1.64 \pm 0.06$ & $1.52-1.73$ \\
Weight $(\mathrm{kg})$ & $60.3 \pm 7.8$ & $49.1-77.4$ \\
$\mathrm{BMl}\left(\mathrm{kg} / \mathrm{m}^{2}\right)$ & $22.66 \pm 3.2$ & $16.3-30.2$ \\
\hline
\end{tabular}

BMI: Body mass index; max: maximum; min: minimum.

It is possible to observe in the Figure 2 that postural alterations are visible according to the difference in loads carried in the backpack, between $0 \%$ and $7 \%$. It can be seen that, with the load of $7 \%$, there is projection of the shoulder, increasing thoracic kyphosis (see blue arrow), and anteriorization of the head. It is also possible to observe the decrease in the angle of the lumbar lordosis, indicated by the yellow arrow, tending to a rectification of the lumbar spine and pelvic retroversion. In addition, the distance between the lower angle of the scapula and the acromion is increased, as opposed to the distance between the elbow and the anterior superior iliac spine, which is decreased (see the black lines).

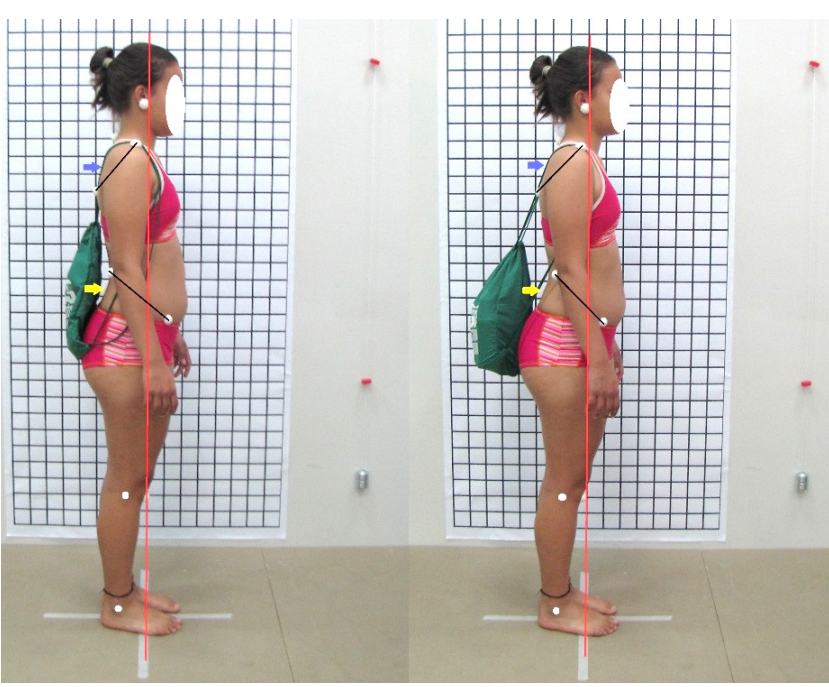

Figure 2. Visual postural alterations according to change in weight carried in backpack (0 and $7 \%$ ). The blue arrow shows the projection of the shoulder indicating thoracic kyphosis. The yellow arrow shows the angle of lumbar lordosis.

It can be observed in Table 2 that there were significant results in the angles of the measurements between the elbow and anterior superior iliac spine when comparing the load values of $0 \%$ with the other percentages $(3 \%, 5 \%, 7 \%$, and $10 \%)$ and, when comparing the load values of $7 \%$ and $10 \%$ with the percentage of $3 \%$. In addition, statistical difference was observed in the data obtained between the measurement of the acromion and anterior superior iliac spine when $0 \%$ of the load was compared to $7 \%$ and $10 \%$. In the other measurements, there were no significant differences.

\section{DISCUSSION}

The main findings of this study indicate that the postural alterations statistically considerable between the analyzed segments happened more frequently when the load value of the backpack was $7 \%$ of the volunteer's body weight, followed by $10 \%$.

In the measures analyzes between the elbow and the anterior superior iliac spine, there was a decrease of the range in the analyzed segment, suggesting 
Table 2. Analysis of the distances obtained at each measurement point, with statistical significance, mean and standard deviation, at each follow-up at $0,3,5,7$, and $10 \%$.

\begin{tabular}{|c|c|c|c|c|c|c|c|c|}
\hline & $0 \%$ & $3 \%$ & $5 \%$ & $7 \%$ & $10 \%$ & $\mathbf{F}$ & $\mathbf{p}$ & Effect size \\
\hline Scapula-Ear & $\begin{array}{c}36.73 \\
(0.45)\end{array}$ & $\begin{array}{l}36.39 \\
(0.51)\end{array}$ & $\begin{array}{c}36.46 \\
(0.51)\end{array}$ & $\begin{array}{l}36.70 \\
(0.48)\end{array}$ & $\begin{array}{l}36.70 \\
(0.52)\end{array}$ & 1.52 & 0.233 & 0.234 \\
\hline Elbow-ASIS & $\begin{array}{l}18.82 \\
(0.56)\end{array}$ & $\begin{array}{c}17.91 \\
(0.61)^{a}\end{array}$ & $\begin{array}{c}17.23 \\
(0.50)^{\mathrm{a}}\end{array}$ & $\begin{array}{l}16.86 \\
(0.50)^{a . b}\end{array}$ & $\begin{array}{l}16.65 \\
(0.54)^{a . b}\end{array}$ & 7.07 & 0.001 & 0.586 \\
\hline C7-Joint line of the knee & $\begin{array}{c}118.76 \\
(0.83)\end{array}$ & $\begin{array}{c}118.79 \\
(0.91)\end{array}$ & $\begin{array}{c}118.99 \\
(0.76)\end{array}$ & $\begin{array}{c}118.85 \\
(0.78)\end{array}$ & $\begin{array}{c}118.51 \\
(0.87)\end{array}$ & 0.49 & 0.739 & 0.090 \\
\hline Acromion-ASIS & $\begin{array}{c}55.72 \\
(0.61)\end{array}$ & $\begin{array}{l}55.23 \\
(0.67)\end{array}$ & $\begin{array}{l}55.31 \\
(0.51)\end{array}$ & $\begin{array}{l}53.60 \\
(1.40)^{a}\end{array}$ & $\begin{array}{l}54.54 \\
(0.57)^{\mathrm{a}}\end{array}$ & 3.26 & 0.032 & 0.395 \\
\hline C7-Ear & $\begin{array}{l}16.51 \\
(0.33)\end{array}$ & $\begin{array}{l}16.56 \\
(0.35)\end{array}$ & $\begin{array}{l}16.40 \\
(0.36)\end{array}$ & $\begin{array}{l}16.45 \\
(0.33)\end{array}$ & $\begin{array}{l}17.95 \\
(1.46)\end{array}$ & 0.37 & 0.824 & 0.070 \\
\hline Elbow-Ear & $\begin{array}{c}60.43 \\
(0.51)\end{array}$ & $\begin{array}{c}60.43 \\
(0.53)\end{array}$ & $\begin{array}{c}60.53 \\
(0.52)\end{array}$ & $\begin{array}{l}60.74 \\
(0.57)\end{array}$ & $\begin{array}{l}60.65 \\
(0.51)\end{array}$ & 0.67 & 0.617 & 0.119 \\
\hline Scapula-ASIS & $\begin{array}{c}45.03 \\
(0.64)\end{array}$ & $\begin{array}{c}44.47 \\
(0.57)\end{array}$ & $\begin{array}{c}44.68 \\
(0.54)\end{array}$ & $\begin{array}{l}45.72 \\
(1.13)\end{array}$ & $\begin{array}{l}44.23 \\
(0.80)\end{array}$ & 2.22 & 0.103 & 0.308 \\
\hline C7-Acromion & $\begin{array}{c}9.27 \\
(0.29)\end{array}$ & $\begin{array}{c}9.46 \\
(0.32)\end{array}$ & $\begin{array}{c}9.83 \\
(0.32)\end{array}$ & $\begin{array}{c}9.72 \\
(0.44)\end{array}$ & $\begin{array}{c}9.80 \\
(0.48)\end{array}$ & 1.09 & 0.384 & 0.180 \\
\hline Malleolus-Ear & $\begin{array}{c}171.61 \\
(1.24)\end{array}$ & $\begin{array}{c}171.26 \\
(1.25)\end{array}$ & $\begin{array}{c}171.35 \\
(1.09)\end{array}$ & $\begin{array}{c}170.13 \\
(2.01)\end{array}$ & $\begin{array}{c}171.20 \\
(1.17)\end{array}$ & 0.574 & 0.684 & 0.103 \\
\hline
\end{tabular}

ASIS: anterior superior iliac spine; C7: $7^{\text {th }}$ cervical vertebrae.

Values described in mean and standard deviation (into parenthesis).

Indice letters: a Significant difference when compared to $0 \%$; ${ }^{\text {b }}$ significant difference when compared to $3 \%$.

the approaching of this points. This finding can be understood considering that when the pelvis is in retroversion, the anterior superior iliac spine tends to be more elevated when compared with its neutral position, in this way, approaching the two analyzed points. The same aspect was identified by Walicka-Cupryś et al. indicated that, when schoolbag weight is greater than $10 \%$, a decrease in lumbar lordosis and a lower tilt of the sacrum is observed, as well as an increase in thoracic kyphosis due to the anterior inclination of the trunk by the users, to balance their center of gravity on the base of support, which corresponds to the area covered by the feet $[14,15]$. This may induce a reduction in the natural curvature of the lumbar spine and related adverse consequences, such as reductions in spinal amortization properties and the asymmetrical impact of the intervertebral discs, which could lead to overload and degenerative alterations of the spine. This posture can become habitual and be maintained even after removal of the backpack [14]. In return, the study by Quixadá et al. showed great significance in the anterior pelvic tilt, using magnetic resonance imaging of the lumbar spine, demonstrating that the greater the school backpack weight, the greater the, causing an anterior pelvic tilt. Such findings were not identified in the present study [9].

Another example of deviations, observed in the current study through visual analysis, is the linear increase in head anteriorization and trunk flexion, which worsens the greater the load supported, interpreted as a compensatory strategy in response to the load effect, this being shown in the present research from the difference statistically meaning found in the measures between the acromion and the anterior superior iliac spine in the comparison between the backpack loaded with $7 \%$ and $10 \%$ of the body weight and the backpack without load $[10,15]$. The same finding of the anterior trunk inclination was described by Arias in one of the systematic studies reviews, confirming the results founded by Kistner et al. during the photographic analysis of the volunteers with the backpack loaded with $10 \%, 15 \%$ and $20 \%$ of the body weight $[16,17]$.

The limitations of the present study are its crosssectional design, which prevents carrying out causality analyzes between backpack weight and postural problems in university students.

Therefore, according to the present study, it was possible to conclude that loads of $7 \%$ are sufficient to promote postural alterations. It is expected that with a new reference value of $7 \%$ allowed for the loading of school backpacks, there will be greater awareness among the university population, favoring the prevention of postural deviations and possible musculoskeletal injuries. 


\section{NOTES}

This study was apresented in National Meeting of Teaching, Research and Extension (ENEPE), 2016.

\section{Funding}

This study did not receive financial support from outside sources.

\section{Conflicts of interest disclosure}

The authors declare no competing interests relevant to the content of this study.

\section{Authors' contributions}

All the authors declare to have made substantial contributions to the conception, or design, or acquisition, or analysis, or interpretation of data; and drafting the work or revising it critically for important intellectual content; and to approve the version to be published.

Availability of data and responsibility for the results

All the authors declare to have had full access to the available data and they assume full responsibility for the integrity of these results.

\section{REFERENCES}

1. Delgado RDCM, Berto R. Distribuição da força plantar em relação ao peso e posicionamento do material escolar. Rev Elet Educ Ciênc. 2015;5(1):25-32.

2. Borges LF, Rodrigues RB, Valente PHF, Nogueira MS, Araújo RF, Alves FAVB, Monteiro APF, Alves AG. Análise postural de alunos de 10 a 12 anos do colégio estadual Américo Antunes, em São Luís de Montes Belos/Go. Rev Elet Fac Montes Belos. 2016;8(3).

3. Dianat I, Sorkhi N, Pourhossein A, Alipour A, Asghari-Jafarabadi M. Neck, shoulder and low back pain in secondary schoolchildren in relation to schoolbag carriage: should the recommended weight limits be gender-specific? Appl Ergon. 2014;45(3):437-42. https://doi.org/10.1016/j.apergo.2013.06.003

4. Shymon SJ, Yaszay B, Dwek JR, Proudfoot JA, Donohue M, Hargens AR. Altered disc compression in children with idiopathic low back pain: an upright MRI backpack study. Spine. 2014;39(3):243. https://doi.org/10.1097/ BRS.0000000000000114

5. Pereira AS, Toigo AM. O peso da mochila escolar relacionado ao peso da criança: análise em alunos de $1^{\mathrm{O}}$ ao 5 o ano do ensino fundamental de uma escola particular de Canoa/RS, Brasil. Rev Aten Saúde. 2014;11(38):16-24. https://doi. org/10.13037/rbcs.vol11n38.1960

6. Hestbaek L, Leboeuf-Y C, Kyvik KO, Manniche C. The course of low back pain from adolescence to adulthood: eight-year follow-up of 9600 twins. Spine. 2006;31(4):468-72. https://doi.org/10.1097/01.brs.0000199958.04073.d9

7. Batista ITS, de Melo-Marins D, Carvalho RGS, Gomes LE. Peso e modo de transporte do material escolar no ensino fundamental I: efeito dos anos escolares e do sexo. Fisioter Pesqui. 2016;23(2):210-5.

8. Silva CB, Naves, ÉA, Beneti GC, Guedes LMD. Influências do peso da mochila escolar em estudantes do ensino fundamental: uma revisão bibliográfica. Rev Méd Minas Gerais, Cidade. 2015;25(2):233-6.

9. Quixadá AP, Ramalho P, Baptista AF, Mendes SMD, Aragão JH, Sá KN. Alterações posturais associadas ao uso de mochilas em escolares. Rev Pesqui Fisioter. 2015;1(1). https://doi.org/10.17267/2238-2704rpf.v1i1.79

10. Ries LG, Martinello M, Medeiros M, Cardoso M, Santos GM. Os efeitos de diferentes pesos de mochila no alinhamento postural de crianças em idade escolar. Motricidade. 2012;8(4):87-95. https://doi.org/10.6063/ motricidade.8(4). 1556

11. Luz Filho CA, Luz KRG, Costa FBS, Vasconcelos JPL, Silva DR. Relação entre peso e transporte da mochila escolar e alterações posturais em escolares de Caxias-MA. Rev Ciênc Saberes Facema. 2015;1(2):124-9.

12. Arias AV, Silva ACO, de Camargo MC. Mochila escolar: investigação quanto ao peso carregado pelas crianças. Fisioter Bras. 2013;376.

13. Souza JA, Pasinato F, Basso D, Corrêa ECR, Silva AMTD. Biofotogrametria confiabilidade das medidas do protocolo do software para avaliação postural (SAPO). Rev Bras Cineantropom Desempenho Hum. 2011;13(4):299-305. https://doi.org/10.5007/1980-0037.2011v13n4p299

14. Walicka-Cupryś K, Skalska-Izdebska R, Rachwał M, Truszczyńska A. Influence of the weight of a school backpack on spinal curvature in the sagittal plane of seven-year-old children. Bio Med Res Int. 2015:817913. https://doi. org/10.1155/2015/817913

15. Lanes TC, Gauron EF, Spratt KF, Wernimont TJ, Found EM, Weinstein JN. Long-term follow-up of patients with chronic back pain treated in a multidisciplinary rehabilitation program. Spine. 1995;20(7):801-6. https://doi. org/10.1097/00007632-199504000-00012

16. Arias AV, Apolinário A, Troster MMRP, Chimello ACR, Carbone ESM, Gimenes RO. O impacto da mochila escolar na marcha: uma revisão de literatura. Rev Bras Ciênc Mov. 2019;26(4):170-80.

17. Kistner F, Fiebert I, Roach K, Moore J. Postural compensations and subjective complaints due to backpack loads and wear time in schoolchildren. Pediatr Phys Ther. 2013;25(1):15-24. https://doi.org/10.1097/PEP.0b013e31827ab2f7 $\in$ 